\title{
Prawda i fikcja w Quo vadis Henryka Sienkiewicza
}

\author{
Truth and Fiction in Quo Vadis by Henryk Sienkiewicz
}

Summary: The aim of the article is to show whether and to what extent literary fiction in $Q u o$ Vadis by Henryk Sienkiewicz contains historical truth. The analysis of historical sources will allow, among others, learning about the historical context or rejecting the stereotypes about Nero as the only person responsible for the fire of Rome or the slaughter of Christians. The carried out comparative literary and historical studies may be utilised while working with students, and selected fragments of historical texts may be suggested to them for studying. The student playing the role of a researcher will certainly become an active and empathic reader of Quo Vadis.

Key words: Quo Vadis, historical truth, literary fiction, Polish language education

Robert Wiśniewski podkreśla, że w Quo vadis prawda historyczna przeplata się z fikcją literacką. Historyk akcentuje, że w narracji Henryka Sienkiewicza jest:

licentia poetica, ale pamiętajmy że jego celem nie było napisanie tekstu naukowego, ale powieści. Obraz ten nie jest jednak absurdalny. Są w jego narracji elementy, które nie są prawdziwe. Wiemy, że chrześcijanie nie spotykali się w katakumbach, które dopiero później były dla nich miejscem pochówku zmarłych. Nie mamy śladów ich obecności w takich miejscach w I wieku. Widzimy je dopiero na przełomie II i III wieku, gdy grzebali zmarłych. Zasadniczy obraz życia miasta, funkcjonowania aparatu cesarskiego i jego dworu oraz życia gminy chrześcijańskiej jest jednak dobrze zakorzeniony w znanych nam i Sienkiewiczowi źródłach historycznych ${ }^{1}$.

${ }^{1}$ R. Wiśniewski: Sienkiewicz w ,Quo vadis”, odbiegt od faktów. http://culture.pl/pl/artykul/ sienkiewicz-w-quo-vadis-odbiegl-od-faktow [data dostępu: 23.12.2017]. 
Spróbujmy razem z historykami przyjrzeć się bohaterom i wydarzeniom ukazanym w powieści Sienkiewicza. Nasze porównania komparatystyczne mogą posłużyć m.in. polonistom do analizy Quo vadis z uczniami. Analizę porównawczą rozpoczniemy od postaci Nerona.

„Miedzianobrody ochrypł. [...] Przeklina Rzym i jego powietrze, na czym świat stoi, rad by go z ziemią zrównać albo zniszczyć ogniem i chce mu się morza jak najprędzej. Powiada, że te zapachy, które wiatr niesie z wąskich uliczek, wtrącą go do grobu" ${ }^{2}$ - przywołany z Quo vadis fragment ukazuje cesarza, który zgodnie z kreacją Sienkiewicza podpali własne miasto. W tym miejscu może pojawić się pytanie dotyczące prawdy historycznej. Jej dociekanie jest trudne, gdyż wiele źródeł historycznych uległo zniszczeniu. Spróbujmy jednak udowodnić za Aleksandrem Wilkoniem, że również w tej powieści Sienkiewicza ,wątek historyczny spleciony jest z fikcyjnym, porządek historii i porządek anegdoty tworzą jedną całość"3. A logiczność i przejrzystość tekstu sprzyja formie kształtowania historycznej iluzji, która jest właściwa dla Sienkiewicza ${ }^{4}$.

Sienkiewicz w powieści zestawił dwa skrajne światy: pogański — zgorszony starogreckimi wierzeniami oraz kształtujący się powoli — chrześcijański. Świat pogański, który reprezentował m.in. Neron, został ukazany jako symbol deprawacji oraz upadających wartości ${ }^{5}$.

Zanim przejdziemy do rozważań dotyczących prawdy i fikcji w powieści, przypomnijmy z jakich źródeł korzystał Sienkiewicz, tworząc własne dzieło. Nie można bowiem odmówić twórcy Trylogii ${ }^{6}$ braku znajomości okresu starożytnego Rzymu, gdyż studiował historię pierwszego wieku już za czasów uniwersyteckich, a nawet szkolnych. Podjął się także tłumaczenia fragmentów dzieł Tacyta ${ }^{7}$. Wiedzę na temat świata starożytnego Imperium Rzymskiego zdobywał Sienkiewicz, studiując dzieła i źródła tamtego okresu oraz odbywając podró-

${ }^{2}$ H. Sienkiewicz: Quo vadis. Powiesśc z czasów Nerona. Oprac. T. Żabski. Wrocław 2002, s. 366.

3 A. Wilkoń: O języku i stylu „Ogniem i mieczem” Henryka Sienkiewicza. Kraków 1976, s. 107.

${ }^{4}$ Zob. T. Bujnicki: Powieść historyczna wedtug Sienkiewicza. Teoria i praktyka. http:// dx.doi.org/10.18778/2299-7458.05.09 [data dostępu: 16.12.2017].

${ }^{5}$ Zob. T. Żabski: Wstęp. W: H. Sienkiewicz: Quo vadis..., s. 6. „Nie służyłaby też Sienkiewiczowi szeroka prezentacja epoki »pax romana« — stabilizacji imperium, trwałego pokoju, zaniechania nowych podbojów [...]. Rozmijały się tematycznie z główną ideą pisarza, kierując "niepotrzebnie« mimowolną sympatię czytelnika w stronę Rzymian, do których przecież należał główny bohater".

${ }^{6}$ Trylogia Sienkiewicza - cykl powieści historycznych autorstwa Henryka Sienkiewicza, które publikowane były w latach 1884-1888. Ich akcja toczy się na terenach I Rzeczypospolitej pod koniec pierwszej połowy i w drugiej połowie XVII wieku.

7 Tacyt (Publius Cornelius Tacitus; ok. 55-120) — jeden z najznakomitszych historyków rzymskich. 
że - do Neapolu w 1886 roku, a później w roku 1893 do Rzymu. Pozwoliło to polskiemu nobliście na literackie oddanie historycznego i kulturowego pejzażu tamtych czasów ${ }^{8}$.

W listach autora Quo vadis czytamy:

Pomysł napisania Quo vadis powstał we mnie pod wpływem czytania $A n$ nałów Tacyta, który jest jednym z najulubieńszych moich pisarzy, i podczas dłuższego pobytu w Rzymie?.

Noblista wielokrotnie powtarzał, że wiedzę na temat epoki cesarzy rzymskich zdobywał, studiując twórczość Tacyta. Z kolei ten ostatni akcentował w swoich Rocznikach:

Ja pójdę za zgodną tradycją historyków, a co odmienne opowiedzieli, to podam pod ich własnym imieniem ${ }^{10}$

i w przeciwieństwie do innych rzemieślników słownych tamtego okresu stawiał na obiektywizm. I tak, chociażby na temat wielkiego pożaru Rzymu w 64 roku autor słynnych Roczników pisze:

Zdarzyło się potem nieszczęście - nie wiadomo, czy z przypadku, czy przez złośliwość cesarza (bo obydwie wersje podają pisarze)... ${ }^{11}$

Natomiast zarówno Swetoniusz ${ }^{12}$ w Żywotach cezarów, jak i Kasjusz Dion ${ }^{13}$ w Historii rzymskiej utrzymywali, że w trakcie wielkiego pożaru cesarz Neron śpiewał pieśń własnego autorstwa Spalenie Troi. Swetoniusz pisze z przekonaniem:

Lecz nie oszczędził także ludu oraz murów ojczystego miasta [...] spalił stolicę tak jawnie, że wielu konsularów, schwytawszy w swych posiadłoś-

${ }^{8}$ Sienkiewicz do każdej powieści historycznej przygotowywał się bardzo sumiennie. Pogłębiał wiedzę na temat epoki. W roku 1894 zapytany przez dziennikarza Władysława Karczewskiego o postęp tworzenia powieści, odpowiedział: „Przygotowania do Quo vadis prowadzę sumiennie. [...] Tacyta studiuję da capo, no i przewertowałem prawie całą bibliotekę dzieł, dotyczących pierwszego wieku naszej ery”. Cyt. za: J. Krzyżanowski: Henryk Sienkiewicz. Kalendarz życia i twórczości. Warszawa 1956, s. 188.

${ }^{9}$ H. Sienkiewicz: Listy. T. I. Cz. 1. Red. J. Krzyżanowski. Warszawa 1997, s. 100.

10 Tacyt: Roczniki. W: Idem: Dzieła. T. I. Tłum. S. Hammer. Warszawa 1957, s. 373.

11 Ibidem, s. 457.

12 Swetoniusz (Gaius Suetonius Tranquillus; ok. 69-130) — pisarz rzymski, pisał po łacinie i po grecku.

${ }_{13}$ Kasjusz Dion (Lucius Cassius Dio Cocceianus; ok. 163/164 - 235) — rzymski historyk pochodzenia greckiego oraz senator i dwukrotny konsul. 
ciach pokojowców cesarza z pakułami i pochodniami, nie śmiało stawić im przeszkód ${ }^{14}$.

Według Tacyta była to jednak plotka, a sam cesarz przebywał wówczas w Ancjum. Kiedy pożar się rozprzestrzenił, cesarz wrócił do Rzymu w celu udzielenia mieszkańcom pomocy humanitarnej, na którą przeznaczył środki z własnego skarbca. Otworzył również pałac dla poszkodowanych, a także zapewnił stałą dostawę żywności. Kiedy pożar dobiegł końca, Neron opracował nowy plan miasta. Miał on spełniać standardy bezpieczeństwa. Aby zapobiec rozprzestrzenianiu się ognia, zaplanował budowę domów z cegły. Pomyślał też o zachowaniu większych odległości między budynkami. Sienkiewicz na ten temat jednak milczy.

Autor Quo vadis opisywał pożar i postawę Nerona w obliczu tragedii, w sposób jednoznaczny: cesarz

nienawidził tego miasta, nienawidził jego mieszkańców, kochał tylko swe pieśni i wiersze; więc radował się w sercu, że wreszcie ujrzał tragedię podobną do tej, którą opisywał. Wierszorób czuł się szczęśliwy, deklamator czuł się natchniony, poszukiwacz wzruszeń poił się strasznym widowiskiem i z rozkoszą myślał, że nawet zagłada Troi niczym była w porównaniu z zagładą tego olbrzymiego grodu. Czegóż mógł jeszcze żądać? ${ }^{15}$

Sienkiewicz prezentuje obraz cesarza Nerona, dla którego pożoga miasta staje się spełnionym marzeniem. Biorąc pod uwagę stanowisko Swetoniusza i Kasjusza, a także Tacyta, nie może dziwić fakt, że Sienkiewicz opowiedział się właśnie za tą wersją, która idealnie wpisywała się w konwencję utworu.

Niemniej jednak dzisiejsi historycy są raczej zgodni, że to nie rozkaz Nerona spowodował pożar. Jak podkreśla Aleksander Krawczuk, cesarz często wychodził na wieżę, aby obserwować przebieg pożaru i akcję ratunkową, stąd też wzięła się plotka, że właśnie na tej wieży z przyjemnością deklamował własne dzieło na tle ludzkiej tragedii. Krawczuk podaje również:

Wielu wrogów Nerona nie tylko powtarzało te plotki, ale jeszcze ubarwiało je w różny sposób ${ }^{16}$.

Przypomnijmy teraz, co źródła historyczne mówią o początkach panowania Nerona. Rok 54 przyniósł Rzymianom nowe nadzieje. Wierzyli, że młody, bo

${ }^{14}$ Swetoniusz: Żywoty cezarów. Tłum. J. Niemirska-Pliszczyńska. Wrocław 1987, s. 258 .

${ }^{15}$ H. Sienkiewicz: Quo vadis..., s. 467.

${ }^{16}$ A. Krawczuk: Neron. Warszawa 1988, s. 237. 
zaledwie siedemnastoletni cesarz pozwoli im zapomnieć o krwawych rządach trzech ostatnich władców: Tyberiusza, Kaliguli i Klaudiusza.

Seneka Młodszy ${ }^{17}$ - wybitny filozof i nauczyciel Nerona - tak opisywał wychowanka w traktacie filozoficznym $O$ lagodności:

Postanowiłem Neronie Cezarze, napisać o łagodności, chcąc spełnić rolę zwierciadła, abyś ujrzał w nim siebie i odczuł największą radość ${ }^{18}$.

Seneka nie był jedynym człowiekiem, który w swoich dziełach opisywał zalety młodego władcy. Nie wiemy jednak, dlaczego tak czynił. Być może liczył na przywileje i dojście do władzy po latach odsuwania go w cień. Pewne jest jednak to, że filozof przez całe swoje życie zmieniał zdanie na temat syna Germanika i Agrypiny ${ }^{19}$.

Zwróćmy teraz uwagę na czas, w którym rozpoczyna się akcja Quo vadis. Neron nie jest już wówczas nadzieją Rzymian na lepszą przyszłość, a tyranem, mającym za sobą wiele zbrodni: zabójstwo matki, brata oraz żony (będącej również jego przyrodnią siostrą). Analiza materiałów źródłowych dowodzi, że autor Quo vadis ukazuje czytelnikom jedynie namiastkę okrucieństw Nerona, o których dowiadujemy się chociażby z rozmowy Aulusa Plaucjusza ${ }^{20}$ i Seneki. Ten ostatni zwraca się do swojego rozmówcy słowami:

Jakże Ci było nie wysławiać śmierci Brytanika, nie powiedzieć mowy pochwalnej na cześć matkobójcy i nie złożyć życzeń z powodu uduszenia Oktawii. Brak ci przezorności, Aulu, którą my, żyjący szczęśliwie przy dworze, posiadamy w stopniu odpowiednim ${ }^{21}$.

Z przywołanego fragmentu dowiadujemy się także o atmosferze panującej na dworze cesarskim. Również arbiter elegantiarum - Petroniusz, uwielbiany przez lud, doskonale zdaje sobie sprawę z przewrotnej natury cesarza, o czym może świadczyć cytat:

17 Seneka Młodszy (Lucjusz Anneusz Seneka (Młodszy); ok. 4 p.n.e. 65 n.e.) - retor, pisarz, poeta, filozof rzymski, zwany Filozofem, syn Seneki Starszego zwanego Retorem. Stoik, piewca heroicznej etyki. Seneka w rzymskiej powieści Sienkiewicza zostaje przedstawiony w roli starca, niepewnego swojej przyszłości, oddalonego od władzy i pozbawionego wpływu na dawnego wychowanka. Sienkiewicz nie opisuje śmierci starego stoika, wymienia go jedynie jako jedną z ofiar po wykryciu spisku Pizona. Tacyt dokładnie przedstawia scenę śmierci Seneki.

18 Seneka: Pisma filozoficzne. Thum. L. Jachimowicz. Warszawa 1965, s. 5.

19 M. Kosman: ,Quo vadis”. Prawda i legenda. Poznań 2000, s. 52.

${ }^{20}$ Aulus Plaucjusz (Aulus Plautius; I wiek n.e.) — rzymski polityk i wojskowy, zasłużony przy podboju Brytanii przez Cesarstwo Rzymskie.

${ }^{21}$ H. Sienkiewicz: Quo vadis..., s. 66. 
pamiętał, że ten lud kochał także i Brytanika, którego Neron otruł, i Agrypinę, którą kazał zamordować - i Oktawię, którą na Pandatarii uduszono po uprzednim otwarciu jej żył w gorącej parze... ${ }^{22}$

Polski noblista w swojej rzymskiej powieści nie opisuje tych trzech wielkich zbrodni Nerona, nie docieka też ich genezy.

Tacyt jednak przedstawia kulisy tych wydarzeń. Rzymski historyk zaczyna chronologicznie, od zabójstwa przyrodniego brata - Brytanika, podkreślając, że w dużej mierze przyczyniła się do tego Agrypina, matka cesarza. Kobieta, przewidując własny upadek, postanowiła wykorzystać pozycję prawowitego spadkobiercy tronu, syna cesarza Klaudiusza, i groziła Neronowi:

dorósł Brytanik, prawdziwa i godna latorośl, żeby po swym ojcu objąć rządy, które intruz i przybraniec z krzywdą matki sprawuje $\mathrm{e}^{23}$.

Pamiętając o wojnie domowej Pompejusza z Juliuszem Cezarem ${ }^{24}$, rozegranej kilkadziesiąt lat wcześniej, Neron mógł przypuszczać, że prędzej czy później dojdzie do konfrontacji z Brytanikiem i tylko jeden z nich przeżyje. Jednym $\mathrm{z}$ argumentów, który mógłby w jakimś stopniu złagodzić winę Nerona, było wybranie mniejszego zła, jakim byłaby wojna domowa. Można również rozpatrywać tę zbrodnię w kategorii obrony życia cesarza przed zwolennikami Brytanika.

Trudniej jest wyjaśnić hańbiący czyn matkobójstwa. Agrypina miała na sumieniu szereg zbrodni i w wielu podaniach ukazana jest jako kobieta bezwzględna. Idąc tym tropem, można myśleć o niebezpieczeństwie zagrażającym Neronowi z jej strony, w momencie kiedy ten odsunął ją od władzy, w końcu jak nadmienia Tacyt — jawnie mu groziła. Hipotez zapewne jest wiele, jednak argumentów na ich poparcie zbyt mało, żeby móc w jakikolwiek sposób usprawiedliwiać ten czyn. Sienkiewicz, chociaż nie poświęca temu wydarzeniu wiele miejsca, daje czytelnikowi do zrozumienia, że Neron, pozbywając się matki, zerwał ostatnie kajdany uzależniające go od kogokolwiek.

Trudno dziś stwierdzić, czy Agrypina bardziej kochała władzę, dla której gotowa była poświęcić nawet jedynego syna, czy wszystko robiła z miłości do niego. Pomimo wątpliwości na temat prawdziwych relacji matki i syna, pewne jest, że cesarz Neron popełnił zbrodnię matkobójstwa. Krawczuk zaznacza, że cesarz:

${ }^{22}$ Ibidem, s. 35.

${ }^{23}$ Tacyt: Roczniki..., s. 368.

${ }^{24}$ Wojna domowa Cezara z Pompejuszem — konflikt o władzę w starożytnym Rzymie toczący się w latach 49-45 p.n.e. pomiędzy Gajuszem Juliuszem Cezarem, prokonsulem i zdobywcą Galii, a Gnejuszem Pompejuszem Wielkim, konsulem rzymskim, który otrzymał poparcie Senatu w obronie wartości republikańskich. 
Zrozumiał, czego się dopuścił, dopiero wtedy, kiedy zameldowano o wykonaniu rozkazu. [...] Owego strachu i poczucia winy nie pozbył się już nigdy ${ }^{25}$.

Inni autorzy, dla których życie Nerona stało się inspiracją do stworzenia powieści, często wykorzystywali drugą wersję; według niej to Agrypina chciała zabić syna, gdy ten odsunął ją od władzy. Takie ujęcie przedstawia Max Gallo w swojej powieści Rzymianie. Neron - panowanie antychrysta. Autor, opisując Agrypinę, używa następujących słów:

Jest gotowa zabić swojego syna, jeśli ten nie ustąpi, a nawet, jeśli ustąpi, gdyż nie ma już do niego zaufania ${ }^{26}$.

Pozostaje jeszcze sprawa Oktawii, której morderstwo należy przypisać bardziej Sabinie Poppei niż samemu Neronowi, choć nie ma wątpliwości, że to on musiał wydać wyrok skazujący córkę cesarza Klaudiusza na śmierć. Owych zbrodni nie można oceniać w oderwaniu od realiów tamtych czasów oraz przypisywać ich wszystkich wyłącznie Neronowi, ponieważ współwinnych było wielu.

Sienkiewicz dostarcza czytelnikom Quo vadis także informacji na temat życia uczuciowego Nerona: po pierwsze, opisując dawną, lecz prawdziwą miłość, którą darzyła go Akte - grecka wyzwolenica, po drugie zaś, przywołując zdeprawowaną i wyrachowaną Sabinę Poppeę, która była bardziej żądna władzy niż szczerej miłości. Czytelnik Quo vadis poznaje obie kobiety w momencie, w którym pewne role zostały już odegrane. Z powieści dowiadujemy się, że Akte

[...] kocha zawsze Nerona miłością smutną i zbolałą, która żyje już nie nadzieją, ale tylko wspomnieniami chwil, w których ów Nero był nie tylko młodszym i kochającym, ale i lepszym ${ }^{27}$.

Z kolei źródła historyczne donoszą, że Akte w przeszłości miała duży wpływ na cesarza. Dzięki niej dojrzał emocjonalnie i uniezależnił się od matki ${ }^{28}$. Sienkiewicz wspomina, że po odsunięciu Akte przez cesarza, nie widziano w niej żadnego zagrożenia. Nawet Poppea nie dołożyła większych starań, by pozbyć się Akte. Sabina odegrała znacznie większą rolę w historii tamtego okresu, gdyż stała w cieniu wielu późniejszych zbrodni władcy.

${ }^{25}$ A. Krawczuk: Neron..., s. 179.

${ }^{26}$ M. Gallo: Rzymianie. Neron - panowanie antychrysta. Tłum. A. Trąbka. Kraków 2008, s. 165 .

${ }^{27}$ H. Sienkiewicz: Quo vadis..., s. 75.

28 Tacyt: Roczniki..., s. 399. 
Tacyt bardzo surowo opisuje Poppeę, eksponując przy tym jej wdzięk, nieprzeciętną urodę oraz spryt i inteligencję, a także brak jakichkolwiek zasad. Ponieważ była kobietą zamężną, najpierw postarano się o usunięcie jej męża Othona, który w tym czasie był przyjacielem samego Nerona (być może dlatego został wysłany na daleką prowincję, zachowując życie). Wspomnianą już prawowitą żonę Oktawię początkowo skazano na wygnanie, ale to nie wystarczyło żądnej władzy Poppei ${ }^{29}$. O drugiej żonie Nerona dowiadujemy się z powieści mniej niż chociażby o Ligii, jednak czytelnik na podstawie kilku fragmentów może ją ocenić. Była to kobieta, która w pewnym okresie (ukazanym również w Quo vadis) cieszyła się dużym wpływem na dworze. U Sienkiewicza czytamy: „Tu włada Poppea, a Nero, od czasu, gdy mu powiła córkę, jest jeszcze bardziej pod jej władzą" ${ }^{30}$. Autor słynnej Trylogii utrzymuje również, że Poppea była kobietą mściwą. Na prośbę Ligii o odesłanie jej przybranym rodzicom Poppea odpowiada: „Więc Ci obiecuję, że dziś jeszcze zostaniesz niewolnicą Winicjusza" "31. Równie wielką niechęcią i wrogością darzyła Ligię Sabina kiedy zmarła jej córka, oskarżała ukochaną Winicjusza o rzucenie uroku na małą Klaudię Augustę. Druga żona Nerona została przez Sienkiewicza ukazana jako symbol kwintesencji kobiecego zła. Bez skrupułów próbowała zaspokajać własne żądze, uwodząc Winicjusza; to ona też stała za otwarciem swego rodzaju chrześcijańskiej „puszki Pandory”, sprowadzając na dwór Chilona, aby ten opowiedział cezarowi o nowej religii i rzucił oskarżenie na chrześcijan za podpalenie miasta $\mathrm{i}$ inne przestępstwa.

Sienkiewicz, wskazując na takie cechy Poppei, jak: brak zahamowań, żądza władzy i bezwzględność, wydaje się raczej zgodny z Tacytem, który pisze:

Ta kobieta posiadała wszystko oprócz uczciwej duszy [...]. Skromność miała na pokaz, a rozwiązłość na użytek; [...] Nigdy nie oszczędzała swego dobrego imienia i nie odróżniała małżonków od gachów; nie ulegając zaś ani własnemu, ani cudzemu uczuciu, tam przenosiła swe kaprysy, gdzie korzyść swą widziała ${ }^{32}$.

Rzymski historyk wspomina również okrucieństwo Poppei, podczas opisu śmierci Oktawii; świadczą o tym słowa:

dodają jeszcze potworniejsze okrucieństwo, bowiem uciętą jej głowę zanoszą do stolicy, aby ją oglądała Poppea ${ }^{33}$.

\footnotetext{
${ }^{29}$ M. Kosman: „Quo vadis”. Prawda i legenda..., s. 57.

${ }^{30}$ H. Sienkiewicz: Quo vadis..., s. 80.

${ }^{31}$ Ibidem, s. 121.

32 Tacyt: Roczniki..., s. 389.

${ }^{33}$ Ibidem, s. 435.
} 
Na przestrzeni wieków zgodnie utrzymywano, że Oktawia była jedną z najtragiczniejszych ofiar cesarza, ponieważ, w przeciwieństwie do innych, niczym nie zawiniła. Lud oddawał jej cześć, gdyż była dla wielu wcieleniem skromności, cnót, ale i wiecznego smutku. W końcu musiała być żoną zabójcy brata, a pośrednio i ojca.

Nie da się natomiast ukryć, że wszyscy dostrzegli prawdziwe uczucie, jakim Neron darzył Sabinę. Swetoniusz akcentuje:

Poppeę pojął za żonę zaraz dwunastego dnia po rozwodzie z Oktawią i ukochał szczególnie ${ }^{34}$.

I chociaż tak bardzo ją pokochał, to dopuścił się morderstwa, o czym mówią zarówno Swetoniusz, Tacyt, jak i Sienkiewicz. Oto trzy doniesienia na ten temat. U Tacyta czytamy: „Po zakończeniu igrzysk zeszła ze świata Poppea wskutek przypadkowego gniewu małżonka” ${ }^{35}$. Z kolei Swetoniusz pisze: „Poppeę pojął za żonę, $[. .$.$] ale nawet i ją zabił kopnięciem nogi za to, że po jego zbyt$ późnym powrocie $\mathrm{z}$ wyścigu jako woźnicy wpadła na niego ze złością, zresztą będąc w ciąży i chora" ${ }^{36}$; u Sienkiewicza zaś czytamy: ,[...] nawet i Poppea padła ofiarą chwilowego uniesienia cesarza" ${ }^{37}$.

Autor Quo vadis prezentuje również inne osoby z grona cesarskiego dworu. Jedną z mocniej wyeksponowanych w powieści postaci jest Petroniusz. Arbiter elegancji nie był przez historyków opisywany tak szczegółowo, jak w obrazie, który prezentuje czytelnikom Sienkiewicz. W rzymskiej powieści Petroniusz ukazany jest jako człowiek niezwykle inteligentny, cieszący się życiem i obdarzony wielką charyzmą, a także sprytem. Góruje on nad większością dworzan nie tylko mądrością, ale i wyszukanym smakiem estetycznym. Petroniusz staje się także jednym z największych sprzymierzeńców Winicjusza i Ligii w ich walce o miłość i przetrwanie. Tacyt nie mówi o nim wiele, ale Sienkiewicz odwołuje się do tego, co rzymski historyk napisał na temat śmierci patrycjusza. Według Tacyta Petroniusz:

Zasiadł do uczty, oddał się drzemce, aby śmierć, aczkolwiek wymuszona, do przypadkowej była podobna. Nawet w testamencie nie schlebiał, jak większość tych, co ginęli, Neronowi ani Tygellinowi, ani żadnej innej wpływowej osobistości, lecz podawszy imiona bezwstydnych chłopców i niewiast, opisał sromoty cesarza i niezwykłość każdej rozpusty; pismo to opatrzył swoją pieczęcią i posłał Neronowi. Następnie pierścień skruszył,

\footnotetext{
${ }^{34}$ Swetoniusz: Żywoty cezarów..., s. 255.

${ }^{35}$ Tacyt: Roczniki..., s. 482.

${ }^{36}$ Swetoniusz: Żywoty cezarów..., s. 255.

${ }^{37}$ H. Sienkiewicz: Quo vadis..., s. 674.
} 
aby się nim później nie posługiwano w celu wtrącenia kogoś w niebezpieczeństwo $^{38}$.

Również Sienkiewicz mistrzowsko opisuje ostatni list Petroniusza do cesarza, nadając mu sarkastyczny ton, o czym może świadczyć chociażby fragment:

Bądź zdrów, lecz nie śpiewaj, zabijaj, lecz nie pisz wierszy, truj, lecz nie tańcz, podpalaj, lecz nie graj na cytrze, tego ci życzy i tę ostatnią przyjacielską radę posyła ci Arbiter elegantiae ${ }^{39}$.

Te wymowne słowa obnażają wszystkie wady Nerona. Sam podpis jest także złośliwą zaczepką cesarza, który był zazdrosny o przydomek Petroniusza, nadany mu przez lud.

O eleganckim patrycjuszu Tacyt pisze także:

[...] przybrany został do grona nielicznych powierników Nerona jako mistrz dobrego smaku, ile że tamten w swym dosycie niczego nie uważał za przyjemne i subtelne jak tylko to, co mu Petroniusz zalecił. Stąd Tygellin zazdrościł mu jako rywalowi, przewyższającemu go w znawstwie rozkoszy ${ }^{40}$.

Sienkiewicz znacznie rozbudowuje tę postać, obdarzając ją swego rodzaju autorską sympatią. Noblista często podkreślał: „Siedzi we mnie za dużo Petroniusza' ${ }^{941}$.

Jednym z głównych wątków Quo vadis jest rodząca się religia chrześcijańska. To właśnie wartości z niej płynące chciał wyeksponować Sienkiewicz. Nie brakuje w powieści głosów reprezentujących stosunek świata pogańskiego do nowej religii:

Lud nienawidzi ich i podejrzewa. Nikt ich nie widział w świątyniach, albowiem bogów naszych poczytują za złe duchy. [...] Nieprzyjaciółmi są rodzaju ludzkiego, nieprzyjaciółmi miasta i twymi ${ }^{42}$.

Znawcom Tacyta czy Swetoniusza owe tezy wydają się znajome. Tacyt na temat chrześcijan pisze:

\footnotetext{
38 Tacyt: Roczniki..., s. 482.

${ }^{39}$ H. Sienkiewicz: Quo vadis..., s. 687.

40 Tacyt: Roczniki..., s. 489.

${ }^{41}$ H. Sienkiewicz: Dzieła. T. LVI. Red. J. Krzyżanowski. Warszawa 1951, s. 110 (list z 18 VII 1903).

${ }^{42}$ H. Sienkiewicz: Quo vadis..., s. 488.
} 
podstawił Neron winowajców i dotknął najbardziej wyszukanymi kaźniami tych, których znienawidzono dla ich sromot a których gmin chrześcijanami nazywał. [...] Schwytano więc naprzód tych, którzy tę wiarę publicznie wyznawali, potem na podstawie ich zeznań ogromne mnóstwo innych, i udowodniono im nie tyle zbrodnię podpalenia, ile nienawiść ku rodzajowi ludzkiemu. A śmierci ich przydano to urągowisko, że okryci skórami dzikich zwierząt ginęli rozszarpywani przez psy albo przybici do krzyżów, [albo przeznaczeni na pastwę płomieni i] gdy zabrakło dnia, palili się służąc za nocne pochodnie. [...] Stąd, chociaż ci ludzie byli winni i zasługiwali na najsurowsze kary, budziła się ku nim litość, jako że nie dla pożytku państwa, lecz dla zadośćuczynienia okrucieństwu jednego człowieka byli traceni ${ }^{43}$.

Również Swetoniusz, który w swoich Żywotach najpierw opisywał zasługi cesarza, podaje:

Ukarano torturami chrześcijan, wyznawców nowego i zbrodniczego zabobonu ${ }^{44}$.

Rzymski historyk nie widzi w tym zajściu nic złego. Wyznawcy Chrystusa nie byli bowiem pozytywnie odbierani przez pogański Rzym, zwłaszcza w jego wyższych sferach, gdyż głosili wyższość życia duchowego nad dobrami materialnymi. Tajemniczość nowej religii była źródłem wszelkich krzywdzących plotek na temat jej wyznawców czy obrzędów. Świadczyć może o tym również fragment z Quo vadis, w którym pogłoski na temat nowej religii i jej wyznawców przytacza czytelnikom Petroniusz, mówiąc że ,zatruwają studnie, mordują schwytane na ulicy dzieci i oddają się rozpuście" ${ }^{" 45}$, jednak kiedy pada podejrzenie, że chrześcijanką może być również Ligia i Pomponia Grecyna, Petroniusz dodaje: „widocznie chrześcijanie nie są tym, za co ich mamy”46.

Z kolei Krawczuk podkreśla również, że ,prześladowania za Nerona były

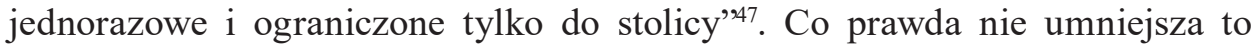
zbrodni dokonanej na chrześcijanach, jednak warto zauważyć, że celem Nerona nie było represjonowanie i ciemiężenie wyznawców Chrystusa, a jedynie zrzucenie na nich odpowiedzialności za podpalenie miasta i pozbycie się „wrogów rodzaju ludzkiego"48. Dziwić może fakt, że dzieła kanoniczne nie podają żadnych szczegółów z tamtego okresu. Relację na temat martyrologii chrześcijan przedstawia Tacyt w swoich dziełach, z których czerpie Sienkiewicz, opisując

\footnotetext{
43 Tacyt: Roczniki..., s. 261.

${ }^{44}$ Swetoniusz: Żywoty cezarów..., s. 243.

${ }^{45}$ H. Sienkiewicz: Quo vadis..., s. 171.

${ }^{46}$ Ibidem.

${ }^{47}$ A. Krawczuk: Neron..., s. 241.

48 Tacyt: Roczniki..., s. 261.
} 
sposoby masowych egzekucji. Oczywiście polski noblista nadaje apologetyczny wydźwięk całemu wątkowi chrześcijańskiemu i w tym przypadku staje w opozycji do starożytnych historyków, dla których wiara w jednego Boga była jedynie niebezpiecznym przesądem.

Kolejnym wydarzeniem zapisanym na kartach historii i wspomnianym przez Sienkiewicza był głośny spisek przeciwko Neronowi, na którego czele stanął niejaki Gajusz Pizon. Rzymscy historycy podają, że przed wykryciem spisku miało miejsce wiele znaków wróżebnych zapowiadających tragedię. Jak podkreślał Tacyt, wśród spiskowców znajdowali się rycerze, senatorowie, żołnierze, a nawet kobiety. Wielu kolaborantów nienawidziło cezara, inni do spisku przystępowali z życzliwości dla Pizona (widzieli w nim następcę Nerona). Sienkiewicz nie opisuje spisku tak dokładnie jak Tacyt. Polskiemu nobliście chodziło głównie o ukazanie narastającego terroru i zdarzeń takich, jak śmierć Petroniusza. Autor rzymskiej powieści pominął wiele ciekawych wątków dotyczących wspomnianego spisku ${ }^{49}$. Sienkiewicz nie trzymał się także skrupulatnie historycznej chronologii, gdyż niektóre wydarzenia opisał niezgodnie z prawdą historyczną (warto w tym miejscu wspomnieć chociażby o występach teatralnych Nerona w Neapolu). Takie rozwiązania kompozycyjne jednak wyjątkowo sprzyjały spójności dzieła.

Po udaremnieniu politycznego przewrotu, Neron czuł się bardziej samotny niż kiedykolwiek wcześniej. Śmierć Sabiny sprawiła, że zamknął się w sobie, gdyż istotnie ubolewał nad skutkiem swojej porywczości. Jedynym sprzymierzeńcem i jedyną miłością cesarza pozostała więc sztuka, której oddawał się jeszcze mocniej - co zaczęło doskwierać ludziom żądnym nowych podbojów i nowej chwały dla Imperium Romanum ${ }^{50}$.

Neron dla historyków zarówno starożytnych, jak i współczesnych, a także dla powieściopisarzy jest niespełnionym artystą, dla którego sztuka stała się wręcz obsesją. Sienkiewicz wiele razy wspomina o artystycznych zamiłowaniach cesarza. Według Nerona:

Dla poezji i sztuki wolno i należy wszystko poświęcić. Szczęśliwi Achaje, którzy dostarczyli Homerowi treści do Iliady, i szczęśliwy Priam, który oglądał zgubę ojczyzny ${ }^{51}$.

Cesarz wielokrotnie podkreślał, że sztuka jest dla niego czymś wyjątkowym i niezastąpionym. Świadczyć o tym może chociażby następująca jego wypowiedź:

${ }^{49}$ Warto wspomnieć chociażby o Epicharis, która była uczestniczką spisku przeciwko Neronowi. Możemy ją poznać, czytając powieść epistolarną Józefa Kraszewskiego. Zob. J.I. Kraszewski: Rzym za Nerona. Warszawa 1987.

${ }^{50}$ R. Holland: Okrutny zbrodniarz rozgrzeszony. Tłum. J. Hołówka. Warszawa 2007, s. 195.

${ }^{51}$ H. Sienkiewicz: Quo vadis..., s. 406-407. 
Gdy gram i śpiewam, widzę takie rzeczy, o których nie wiedziałem, że istnieją w państwie moim lub na świecie. Oto jestem cezarem i świat należy do mnie, mogę wszystko. A jednak muzyka odkrywa mi nowe królestwa, nowe góry i morza, i nowe rozkosze, których nie znałem dotąd [...]. Tylko wielcy artyści mogą się czuć wobec sztuki małymi ${ }^{52}$.

Warto jednak postawić pytanie: jak naprawdę prezentował się doskonały głos władcy, który oczarował bogobojną Ligię na jednej z uczt? Petroniusz na temat wierszy Nerona mówi:

Nie są gorsze od innych. Lukan ma w jednym palcu więcej talentu, ale i w Miedzianobrodym coś jest. Jest przede wszystkim niezmierne zamiłowanie do poezji i muzyki. [...] Czasem mi go żal. Na Polluksa! Co to za dziwna mieszanina! Kaliguli brakowało piątej klepki, ale nie był jednak takim dziwotworem ${ }^{53}$.

Sienkiewicz nie wymyślił sobie zamiłowania Nerona do sztuki, wspomina o tym również Tacyt, podając, że cesarz już od dzieciństwa wykazywał zainteresowanie sztuką, które towarzyszyło mu przez całe życie. Jednak Swetoniusz i Kasjusz Dion w swoich opisach byli bardziej krytyczni, kiedy podawali informacje na temat głosu cezara. Swetoniusz opisywał go jako „głucho brzmiący” i „słaby”. Autor Żywotów nadmienia przy tym, że władca nigdy nie wydawał cudzych dzieł pod własnym imieniem, jak niektórzy sądzili.

Neron w obrazie Sienkiewicza chciał uchodzić za najwybitniejszego artystę świata, więc nie pozwalał sobie na konkurencję, usuwając rywali. Nerona nie interesowały wojny, strategie, poszerzanie granic Imperium Rzymskiego. Cesarz chciał przede wszystkim być uwielbiany i doceniany. Autor Quo vadis bardzo mocno eksponuje obraz władcy-artysty, ale zdaje się być w tym zgodny z rzymskimi historykami starożytnymi.

Sienkiewicz, opisując w epilogu śmierć Nerona, po raz ostatni ukazuje jego tchórzostwo i dramatyczne błazeństwo. Cezar chciał odejść w sposób spektakularny i teatralny, jednak nie miał na tyle odwagi, by samemu odebrać sobie życie. Do końca nie wychodził z roli, powtarzając kilkukrotnie: „Jakiż artysta ginie!". Słowa te Sienkiewicz przytacza za rzymskimi historykami tamtego okresu, które miały brzmieć: Qualis artifex pereo $!^{54}$ - w dosłownym tłumaczeniu: ,jakimż artystą będąc, ginę!" 55 . Zdanie to pojawia się w wielu powieściach, ukazujących życie i haniebną śmierć Nerona. Cezar chciał, aby pamięć o nim

\footnotetext{
52 Ibidem, s. $413-414$.

53 Ibidem, s. 408.

${ }^{54}$ Swetoniusz: Żywoty cezarów..., s. 266.

55 Ibidem.
} 
przetrwała wieki i tak też się stało. Nie był to jednak, ,pomnik trwalszy niż ze spiżu", jak w przypadku Horacego, tylko pomnik obleczony cudzym cierpieniem i cudzą krwią.

Według historyka Richarda Hollanda śmierć cesarza-artysty pociągnęła za sobą swego rodzaju katastrofę. Senatorzy byli przekonani, że wraz z pozbyciem się Nerona, zapobiegną wojnie domowej. Jednak historia pokazała, że Galba nie miał większych predyspozycji do zarządzania Imperium Rzymskim. Rzym nie został uleczony, ale śmierć Nerona zakończyła pewien rozdział w historii Wiecznego Miasta ${ }^{56}$.

Reasumując: podczas rozmowy z uczniami o Quo vadis jako powieści historycznej należy akcentować, że wątek historyczny mocno spleciony jest w niej z fikcyjnym. Przypomnijmy, że historyk Wiśniewski zaznaczał, że obraz Rzymu nie jest jednak absurdalny, chociaż niektóre opisane wydarzenia i bohaterowie są nieco przerysowani, co próbowaliśmy udowodnić.

Warto zaproponować uczniom różne zadania, których celem będzie przybliżenie (pewna charakterystyka) Nerona i innych bohaterów powieści. Zadania mogą np. przybrać następującą postać:

\section{Zadanie 1.}

Podczas lekcji uczniowie dzielą się na cztery grupy. Każda z nich losuje kopertę z nazwiskiem jednego z bohaterów powieści. Wśród nich są: Neron, Sabina Poppea, Petroniusz, Tygellin. Następnie nauczyciel udostępnia każdej grupie ksero odpowiednich fragmentów dzieł Tacyta oraz książki Krawczuka pt. Neron (dotyczą one wyłącznie postaci opisywanych przez daną grupę). Uczniowie w zespołach przygotowują dwa opisy postaci - jeden historyczny, a drugi literacki. Na końcu zapisują w formie tabeli spostrzeżenia dotyczące podobieństw i różnic w obu opisach i formułują wnioski na temat ukazania prawdy historycznej w dziele noblisty.

\section{Zadanie 2.}

Uczniowie, pracując w czterech grupach, wyszukują informacje na temat Nerona zarówno w Quo vadis, jak i materiałach przygotowanych przez nauczyciela (dzieła Tacyta, praca Krawczuka pt. Neron). Jedna grupa skupia się na wyglądzie, druga na cechach charakteru, trzecia na artystycznych zainteresowaniach władcy, a czwarta na przypisywanych mu czynach. Następnie każda grupa przygotowuje tabelkę, w której będzie zapisywać różnice i podobieństwa (uczniowie zwrócą uwagę, że ostatnia grupa znajdzie najwięcej różnic). Po prezentacji każdej z grup młodzież sformułuje własne refleksje na temat sposobu ukazania postaci Nerona w dziele noblisty oraz w tekstach historycznych. Uczniowie powinni podjąć próbę odpowiedzi na pytanie, dlaczego Sienkiewicz

\footnotetext{
${ }^{56}$ R. Holland: Okrutny zbrodniarz rozgrzeszony..., s. 226.
} 
przedstawił Nerona tak demonicznie. Należy przy tym zaznaczyć, że autor miał dostęp do dzieł Tacyta.

\section{Zadanie 3.}

Sąd nad Neronem. Klasa zostaje podzielona na trzy grupy: oskarżycieli, obrońców i sędziów. Pierwsza grupa będzie miała za zadanie, pod okiem lidera-prokuratora, udowodnić na podstawie odpowiednich fragmentów lektury, że Sienkiewicz przedstawił władcę jako tyrana. $Z$ kolei oskarżyciele wyszukują fragmenty opisujące wszystkie zbrodnie cesarza, a także opisują motywacje, jakimi kierował się władca. Druga grupa, wykorzystując źródła historyczne, będzie próbowała znaleźć dowody, które mogłyby ukazać Nerona z innej perspektywy, m.in. wskazać czynniki usprawiedliwiające poczynania władcy. Trzecia grupa to sędziowie, którzy wysłuchując wszystkich postulatów, przeanalizują zebrane dowody, zastanawiając się, czy Sienkiewicz słusznie ukazał w swoim dziele Nerona jako największego tyrana w dziejach ludzkości. Uczniowie mogą skorzystać zarówno z dzieł Tacyta, jak i twórczości Krawczuka (Poczet cesarzy rzymskich, Neron).

\section{Bibliografia}

Gallo M.: Rzymianie. Neron - panowanie antychrysta. Tłum. A. Trąbka. Kraków 2008.

Holland R.: Okrutny zbrodniarz rozgrzeszony. Tłum. J. Hołówka. Warszawa 2007.

Kosman M.: „, Quo vadis”. Prawda i legenda. Poznań 2000.

Kraszewski J.I.: Rzym za Nerona. Warszawa 1987.

Krawczuk A.: Neron. Warszawa 1988.

Krawczuk A.: Spotkania z Petroniuszem. Warszawa 2005.

Krzyżanowski J.: Henryk Sienkiewicz. Kalendarz życia i twórczości. Warszawa 1956.

Petroniusz: Satyryki. Tłum. M. Brożek. Wrocław 1968.

Seneka: Pisma filozoficzne. Tłum. L. Jachimowicz. Warszawa 1965.

Sienkiewicz H.: Dzieła. T. LVI. Red. J. Krzyżanowski. Warszawa 1951.

Sienkiewicz H.: Listy. T. I. Red. J. Krzyżanowski. Warszawa 1997.

Sienkiewicz H.: Quo vadis. Powieść z czasów Nerona. Oprac. T. Żabski. Wrocław 2002.

Swetoniusz: Żywoty cezarów. Tłum. J. Niemirska-Pliszczyńska. Wrocław 1987.

Tacyt: Roczniki. W: Idem: Dzieła. T. I. Tłum. S. Hammer. Warszawa 1957.

Vandenberg P.: Neron. Tłum. P. Taracha. Warszawa 2001.

Wilkoń A.: O języku i stylu „Ogniem i mieczem” Henryka Sienkiewicza. Kraków 1976.

Żabski T.: Wstęp. W: H. Sienkiewicz: Quo vadis. Powieść z czasów Nerona. Wrocław 2002. 


\section{Źródła internetowe}

Bujnicki T.: Powieść historyczna wedtug Sienkiewicza. Teoria i praktyka. http://dx.doi.org/ 10.18778/2299-7458.05.09.

Wiśniewski R.: Sienkiewicz w „Quo vadis” odbiegt od faktów. http://culture.pl/pl/artykul/sien kiewicz-w-quo-vadis-odbiegl-od-faktow. 